\title{
THE INFLUENCE OF FORGIVENESS, GRATITUDE, AND DURATION OF MARRIAGE TOWARD MARITAL SATISFACTION ON WIFES IN SOUTH JAKARTA
}

\author{
Firas Nabila Yusuf \\ nabilafirass@gmail.commailto:afifah.fauzi \\ yyah.af@gmail.com \\ Anggota HIMPSI Provinsi Jawa Barat
}

\author{
Rena Latifa \\ rena.latifa@gmail.com \\ Fakultas Psikologi UIN Syarif \\ Hidayatullah Jakarta
}

\begin{abstract}
The aim of this study is to examine how the relationships between forgivenss, gratitude, and duration of marriage toward marital satisfaction in wifes at South of Jakarta. Marital satisfaction is a personal feeling that strongly related to helath and happiness of marriage. Subjects for this study were 247 wifes at South of Jakarta and 50 wifes were apply for divorce at Religious Courts of South Jakarta. The instrument used was TRIM-18 Inventory (Transgression-Related Interpersonal Motivations-18 Inventory), GRAT (Gratitude, Resentment, and Appreciation Test), and EMS (Enrich Marital Satisfaction). Results indicated that forgiveness and gratitude have significant relationship with marital satisfaction. But, one of dimensions of forgiveness, benevolence motivations, doesn't have significant relationship with marital satisfaction. So as duration of marriage.
\end{abstract}

Keyword: marital satisfaction, forgiveness, gratitude, duration of marriage

\begin{abstract}
Abstrak
Penelitian ini bertujuan untuk mengetahui bagaimana pengaruh Pemaafan, Rasa Syukur, Usia Pernikahan terhadap Kepuasan Pernikahan pada Istri di Jakarta Selatan. Kepuasan Pernikahan merupakan perasaan individu yang berhubungan erat dengan kesehatan dan kebahagiaan dalam pernikahan. Penelitian ini menggunakan metode analisis regresi dengan responden sebanyak 247 istri yang berada di wilayah Jakarta Selatan dan terdapat 50 istri yang sedang mengajukan gugat cerai di Pengadilan Agama Kota Jakarta Selatan. Alat ukur yang digunakan adalah skala TRIM-18 Inventory (Transgression-Related Interpersonal Motivations-18 Inventory), GRAT (Gratitude, Resentment, and Appreciation Test), dan EMS (Enrich Marital Satisfaction). Hasil menunjukkan terdapat pengaruh yang signifikan pemaafan dan rasa syukur terhadap kepuasan pernikahan. Namun, salah satu dimensi pemaafan, yaitu benevolence motivations tidak memberikan pengaruh yang signifikan terhadap kepuasan pernikahan. Begitu pula dengan usia pernikahan.
\end{abstract}

Kata kunci: $\quad$ kepuasan pernikahan, pemaafan, rasa syukur, usia pernikahan 


\section{PENDAHULUAN}

Dalam rentang kehidupan, seorang individu baik pria maupun wanita akan melewati fase demi fase. Banyak ahli psikologi perkembangan mencetuskan teori yang berhubungan dengan hal tersebut, misalnya Jean Piaget dengan teori perkembangan kognitif, teori perkembangan bahasa oleh Chomsky, teori perkembangan psikososial Erik Erikson, dan masih banyak lagi. Berdasarkan teori perkembangan psikososial oleh Erik Erikson, masa dewasa awal adalah pria atau wanita yang berusia 20 hingga 30 tahun dan termasuk dalam fase intimacy vs isolation. Pada fase ini seseorang membutuhkan pengalaman mengenai cinta dan komitmen personal serta tidak terisolasi.

Pada fase dewasa awal, individu akan membangun hubungan dekat dengan orang lain dan siap untuk memiliki komitmen personal dalam kehidupannya. Sebaliknya, apabila individu gagal pada fase ini maka akan mengalami keterasingan dan jarak dalam interaksi dengan orang lain. Untuk itu, pernikahan menjadi suatu hubungan yang penting pada masa dewasa awal karena pernikahan merupakan hubungan yang dilandasi oleh cinta dan komitmen. Hal ini sejalan dengan hasil penelitian yang dilakukan oleh Larson dan Holman (dalam Rosen-Grandon, Myers, \& Hattie, 2004) bahwa pernikahan dinyatakan sebagai hubungan yang paling penting dan mendasar karena pernikahan menyediakan struktur utama untuk membangun suatu keluarga dan meneruskan generasi berikutnya. Namun, pernikahan bukan semata-mata menyatukan seorang pria dan wanita di bawah satu atap, namun lebih dari itu. Setiap individu dengan masing-masing karakter, kepribadian, serta pengalaman masa lalu yang berbeda akan menjalani kehidupan dan melakukan kegiatan bersama, seperti pengambilan keputusan dan pemecahan masalah. Untuk itu, tidak heran apabila dalam dinamikanya terjadi konflik antara suami dan istri. Bahayanya adalah ketika konflik terjadi secara terus menerus hingga berujung pada perceraian. berdasarkan data yang didapatkan dari Pengadilan Agama Jakarta Selatan pada tahun 2015 tercatat 2627 kasus cerai gugat dan 929 kasus cerai talak. Hal ini menjadi semakin menarik perhatian bahwa kasus perceraian yang terjadi didominasi oleh cerai gugat istri terhadap suami dibanding sebaliknya. Faktorfaktor yang meyebabkan perceraian diantaranya adalah gangguang pihak ketiga, tidak ada tanggung jawab, kekerasan dalam rumah tangga, serta masalah ekonomi. Namun, penyebab dengan angka terbesar ialah tidak adanya keharmonisan dalam menjalani kehidupan rumah tangga (http://pajakartaselatan.go.id/en/2015 diakses pada 12 Maret 2016).

Berdasarkan Kamus Besar Bahasa Indonesia (2008), keharmonisan berasal dari kata harmonis yang berarti serasi, selaras. Untuk itu, sebagai penyebab perceraian tertinggi di daerah Jakarta Selatan, ketidakharmonisan dalam rumah tangga dapat dikatakan tidak adanya keserasian dan keselarasan dalam kehidupan rumah tangga dan memicu perselisihan yang terus menerus antara suami dan istri. Perselisihan yang terjadi secara terus menerus dan tidak dapat berakhir atau terselesaikan, dapat menjadi salah satu indikasi tidak adanya kepuasan dalam pernikahan dan dapat berujung perceraian. Sebagaimana hasil penelitian yang dilakukan oleh Fan \& Lui (2004), menyebutkan bahwa 
perubahan yang dirasakan dalam kepuasan pernikahan merupakan suatu faktor penting dalam membuat keputusan bercerai.

Pengertian kepuasan pernikahan adalah perasaan yang bersifat subjektif dari pasangan suami istri mengenai perasaan bahagia, puas, dan menyenangkan terhadap pernikahan secara menyeluruh (Olson \& DeFrain, 2006). Untuk itu, kepuasan pernikahan hanya dapat dinilai oleh individu yang menjalani hubungan pernikahan bersama pasangannya. Sedangkan faktor yang memengaruhi kepuasan pernikahan diantaranya adalah komitmen seumur hidup terhadap pasangan, kesetiaan terhadap pasangan, keinginan untuk membahagiakan dan mendukung pasangan, menjadi pendamping yang baik untuk pasangan, keinginan untuk meminta maaf dan dimaafkan (Fenell, dalam Rosen-Gradon, et.al., 2004), rasa syukur (Algoe, Gable, \&Maisel, 2010), dan usia pernikahan (Huston, dalam Igbo, Grace, \& Ikoja, 2012). Namun, untuk mencapai dan mempertahankan kepuasan dalam pernikahan bukanlah hal yang mudah. Sebagaimana yang dinyatakan oleh Rosen-Grandon, et.al., (2004) pernikahan menjadi hubungan yang paling diinginkan, namun secara statistik mengindikasikan bahwa kepuasan pernikahan tidak mudah untuk dicapai. Untuk itu, bukanlah suatu hal yang mengherankan apabila terdapat banyak kasus pernikahan yang berakhir dengan perceraian pada pasangan yang menikah.

Terdapat beberapa faktor yang memengaruhi kepuasan pernikahan, diantaranya adalah Pemaafan (Fincham, Paleri, \& Regalia (2005) dalam hubungan yang intim dapat memberikan pengaruh pada tingkat kepuasan pasangan Selain itu, individu yang berada dalam suatu hubungan pernikahan jangka panjang melaporkan keinginan untuk memaafkan sebagai suatu konstruk yang memperpanjang dan mempertahankan kepuasan pernikahan. Selain itu, rasa syukur juga menjadi salah satu faktor yang dapat mempengaruhi kepuasan pernikahan Algoe, et.al., (2010). Schramm, Marshall, \& Harris, (2005) menyebutkan bahwa pasangan yang baru menikah mendapatkan manfaat dari hubungan mereka dikarenakan rasa syukur untuk pasangannya berhubungan dengan semakin tingginya kepuasan pernikahan dan penyesuaian yang lebih baik dalam pernikahan. Terakhir, dalam penelitian longitudinal yang dilakukan oleh Huston (dalam Igbo, et.al., 2012) ditemukan suatu penurunan substansial dalam kepuasan pernikahan selama tahun-tahun pertama pernikahan dan penelitian yang dilakukan oleh Glenn (dalam Igbo, et.al., 2012) menemukan bahwa kepuasan pernikahan diindikasikan oleh persentase yang terus menurun dari individu yang mengaku pernikahan mereka "sangat menyenangkan" dalam 10 tahun dan mungkin 25 tahun lebih lama.

\section{KAJIAN TEORI}

\section{Kepuasan Pernikahan}

Dari beberapa definisi di atas, kepuasan pernikahan dapat diartikan sebagai perasaan yang bersifat subjektif dari pasangan suami istri mengenai perasaan bahagia, puas, dan menyenangkan terhadap pernikahannya secara menyeluruh, sebagaimana yang disebutkan oleh Olson dan DeFrain (2006). 


\section{Pemaafan}

Berdasarkan beberapa definisi yang telah dipaparkan di atas, pengertian pemaafan yang digunakan pada penelitian ini mengacu pada teori yang diungkapkan oleh McCullough (2001), yaitu kesediaan menanggalkan kesalahan yang dilakukan individu yang telah menyakiti hati atau melakukan suatu perbuatan salah pada individu lain.

\section{Syukur}

Berdasarkan beberapa penjelasan yang telah disebutkan mengenai rasa syukur, penulis merujuk pada definisi oleh Watkins, Woodward, Stone, dan Kolts (2003) yaitu, perasaan mengenai apresiasi bersyukur atas kebaikan yang diterima, tidak merasa kekurangan, mengetahui kontribusi dari orang lain, dan mengapresiasi kesenangan sederhana.

\section{Usia Penikahan}

Usia pernikahan atau lamanya pernikahan adalah waktu antara hari, bulan, dan tahun ketika menikah hingga saat ini (Igbo, Grace, \& Christina, 2015). Lebih ditegaskan lagi dalam kamus istilah statistik (dalam Igbo, et.al., 2015) bahwa durasi pernikahan ini sering diungkapkan dalam tahun.

\section{METODE PENELITIAN}

\section{Populasi, sampel dan teknik pengambilan sampel}

Dalam penelitian ini yang dijadikan populasi adalah individu yang yang berstatus sebagai istri dan telah terikat dalam hubungan pernikahan heteroseksual. Sedangkan sampel penelitian ini adalah individu yang berstatus sebagai istri dan menikah untuk pertama kali, serta berada di wilayah Jakarta Selatan. Jumlah sampel dalam penelitian ini sebanyak 247 istri, lebih rincinya terdiri dari 197 istri secara umum dan terdapat 50 istri yang sedang mengajukan gugat cerai di Pengadilan Agama Jakarta Selatan pada tahun 2016. Pengambilan sampel pada penelitian ini bersifat non probability sampling yang berarti kemungkinan terpilihnya anggota populasi yang akan menjadi sampel tidak dapat ditentukan. Penulis menggunakan convenience sampling, yaitu yang sesuai dengan kriteria sampel.

\section{Instrumen penelitian}

Instrumen pengumpulan data dalam penelitian ini terdiri dari tiga alat ukur.

Adapun tiga alat ukur tersebut, yaitu:

1. Skala kepuasan pernikahan

Untuk mengukur kepuasan pernikahan dari individu, penulis menggunakan alat ukur ENRICH Marital Satisfaction (EMS) oleh Fowers dan Olson (1993). Alat ukur ini terdiri dari sepuluh dimensi. Respon jawaban untuk item ini menggunakan format skala likert 5 poin, mulai dari 1 (tidak pernah) sampai 5 (selalu). 


\section{Skala Pemaafan}

Untuk mengukur perilaku pemaafan dari individu, alat ukur yang digunakan dalam penelitian ini adalah TRIM-18 (Transgression-Related Interpersonal Motivations) oleh McCullough, et.al., (2006). Skala ini terdiri dari 18 item yang mencakup tiga dimensi, yaitu avoidance motivations, revenge motivations dan benevolence motivations. Respon jawaban untuk item ini menggunakan format skala likert 5 poin, mulai dari 1 (tidak pernah) sampai 5 (selalu).

3. Skala rasa syukur

Alat ukur yang digunakan untuk mengukur perilaku rasa syukur adalah GRAT (Gratitude Resentment and Appreciation Test) oleh Watkins, et.al., (2003). Skala ini terdiri dari 15 item yang meliputi dimensi lack of sense of deprivation, simple appreciation, dan social appreciation. Respon jawaban untuk item ini menggunakan format skala likert.

\section{HASIL PENELITIAN}

Besaran Muatan Independent Variable terhadap Dependent Variable

\section{Hasil uji hipotesis}

Tabel 1

Analisis Regresi

\begin{tabular}{lllll}
\hline Model & $\mathbf{R}$ & $\boldsymbol{R}$ Square & Adjusted $\boldsymbol{R}$ Square & Std. Error of the Estimate \\
\hline 1 & $.925^{\mathrm{a}}$ & .855 & .851 & 3.864 \\
\hline
\end{tabular}

Berdasarkan tabel di atas, didapatkan proporsi varians dari kepuasan pernikahan yang dijelaskan semua independen variabel adalah sebesar $85.5 \%$, sedangkan $14.5 \%$ sisanya dipengaruhi oleh variabel lain di luar penelitian ini.

\section{Tabel 2}

Anova pengaruh keseluruhan IV terhadap DV

\begin{tabular}{llllll}
\hline Model & Sum of Squares & Df & Mean Square & F & Sig. \\
\hline Regression & 21031.390 & 7 & 3004.484 & 201.219 & $.000^{\mathrm{b}}$ \\
Residual & 3568.610 & 239 & 14.931 & & \\
Total & 24600.000 & 246 & & & \\
\hline
\end{tabular}

Diketahui bahwa nilai signifikansi lebih kecil $(\mathrm{p}<0.05)$, maka hipotesis nihil yang menyatakan tidak ada pengaruh yang signifikan seluruh independent variable terhadap dependent variable, yaitu kepuasan pernikahan ditolak. Artinya, ada pengaruh yang signifikan dari pemaafan, rasa syukur, dan usia pernikahan terhadap kepuasan pernikahan. 
Tabel 3

Koefisien regresi

\begin{tabular}{lrrrr}
\hline Model & $\begin{array}{c}\text { Unstandardized } \\
\text { Coefficients }\end{array}$ & Standardized Coef & $\mathbf{t}$ \\
& \multicolumn{1}{c}{ B } & SE & Beta & \\
(Constant) & -2.308 & 1.842 & & -1.253 \\
Avoidance Motivations & .121 & .053 & .120 & 2.271 \\
Revenge Motivations & .099 & .047 & .072 & 2.116 \\
Benevolence Motivations & -.012 & .060 & -.012 & -.209 \\
Sense of Abundance & .308 & .054 & .308 & 5.703 \\
Simple appreciation & .171 & .072 & .171 & 2.365 \\
Social Appreciation & .341 & .074 & .342 & 4.625 \\
Usia Pernikahan & .579 & .327 & .044 & 1.773 \\
& & & &
\end{tabular}

a. Dependent Variable: Kepuasan pernikahan

dapat disampaikan persamaan regresi sebagai berikut: (*signifikan)

Kepuasan pernikahan $=-1.652+0.121^{*}$ avoidance motivations $+0.099 *$ revenge motivations -0.012 benevolence motivations $+0.308 *$ sense of abundance $+0.171 *$ simple appreciation +0.341 social appreciation +0.579 usia pernikahan untuk melihat signifikan atau tidaknya koefisien regresi yang dihasilkan, dapat melihat nilai sig. pada kolom paling kanan (kolom ke-6), jika $\mathrm{p}<0.05$, maka koefisien regresi yang dihasilkan signifikan pengaruhnya terhadap kepuasan pernikahan dan sebaliknya. Dari hasil di atas, koefisien regresi avoidance motivations, revenge motivations, sense of abundance, simple appreciation, dan social appreciation memiliki pengaruh yang signifikan, sedangkan sisanya tidak.

\section{Proporsi varian}

1. Variabel avoidance motivations memberikan sumbangan sebesar $67.8 \%$ dalam varians kepuasan pernikahan.

2. Variabel revenge motivations memberikan sumbangan sebesar $0.9 \%$ dalam varians kepuasan pernikahan.

3. Variabel benevolence motivations memberikan sumbangan sebesar $6.9 \%$ dalam varians kepuasan pernikahan.

4. Variabel sense of abundance memberikan sumbangan sebesar $4.5 \%$ dalam varians kepuasan pernikahan.

5. Variabel simple appreciation memberikan sumbangan sebesar $3.9 \%$ dalam varians kepuasan pernikahan.

6. Variabel social appreciation memberikan sumbangan sebesar $1.3 \%$ dalam varians kepuasan pernikahan.

7. Variabel usia pernikahan memberikan sumbangan sebesar $0.2 \%$ dalam varians kepuasan pernikahan. 


\section{KESIMPULAN DAN SARAN}

\section{Kesimpulan}

Berdasarkan hasil uji hipotesis penelitian yang telah dilakukan sebelumnya, maka diperoleh kesimpulan dari penelitian ini, bahwa secara keseluruhan ada pengaruh yang signifikan antara pemaafan, rasa syukur, dan usia pernikahan terhadap kepuasan pernikahan pada istri di wilayah Jakarta Selatan. Berdasarkan proporsi varians yang telah dihitung, diperoleh hasil bahwa pemaafan, rasa syukur, dan usia pernikahan memiliki pengaruh sebesar $85.5 \%$ terhadap kepuasan pernikahan. Hal tersebut ditunjukkan dari hasil uji $\mathrm{F}$ yang menguji seluruh independent variabel (IV) terhadap dependent variabel (DV). Maka hipotesis mayor yang menyatakan bahwa terdapat pengaruh yang signifikan antara pemaafan, rasa syukur, dan usia pernikahan terhadap kepuasan pernikahan pada istri di Jakarta Selatan tidak ditolak. Dari hasil penelitian menunjukkan bahwa pengaruh antara variabel pemaafan, rasa syukur, dan usia pernikahan, terdapat lima variabel yang memiliki pengaruh signifikan terhadap kepuasan pernikahan. Kelima variabel tersebut adalah avoidance motivations, revenge motivations, sense of abundance, simple appreciation, dan social appreciation.

\section{Diskusi}

Dari hasil penelitian menunjukkan bahwa pengaruh antara variabel pemaafan, rasa syukur, dan usia pernikahan, terdapat lima variabel yang memiliki pengaruh signifikan terhadap kepuasan pernikahan. Kelima variabel tersebut adalah avoidance motivations, revenge motivations, sense of abundance, simple appreciation, dan social appreciation.

Pada penelitian ini terbukti bahwa pemaafan memiliki pengaruh yang postif terhadap kepuasan pernikahan. Hal ini sejalan dengan penelitian yang dilakukan oleh Mirzadeh dan Fallahchai (2012) yang menyebutkan bahwa semakin tinggi pemaafan maka akan berhubungan secara signifikan dengan semakin tinggi pula kepuasan pernikahan. Avoidance motivations sebagai dimensi dari variabel pemaafan memiliki pengaruh yang signifikan terhadap kepuasan pernikahan. Avoidance motivations pada penelitian ini berarti istri memiliki motivasi yang rendah untuk menjauhi orang yang bersalah, dalam hal ini suami.

Sedangkan revenge motivation dalam penelitian ini berarti seorang istri memiliki motivasi yang rendah untuk balas dendam terhadap suami atas kesalahan yang telah dilakukan. Revenge motivation memiliki nilai yang positif dan signifikan terhadap kepuasan pernikahan, berarti semakin tinggi revenge motivation, maka semakin tinggi pula kepuasan pernikahan. Sebagaimana yang disebutkan Fincham, Paleari, Regalia (2009), bahwa semakin individu memaafkan dan sedikit menghindar serta balas dendam terhadap pasangannya, maka pasangan suami istri akan semakin puas, dekat, dan suportif dalam hubungan pernikahan.

Berikutnya, pada penelitian ini ditemukan bahwa rasa syukur memiliki pengaruh yang positif serta signifikan terhadap kepuasan pernikahan. Hal ini sejalan dengan hasil penelitian yang dilakukan oleh Algoe, Gable, dan Maisel (2010) yang menemukan bahwa rasa syukur diprediksi meningkatkan kepuasan 
dalam suatu hubungan, baik untuk yang memberikan kebaikan ataupun yang menerima.

Sense of abundance sebagai salah satu dimensi rasa syukur dalam penelitian ini merupakan pasangan yang secara positif merasa kelebihan dalam kehidupan rumah tangganya dan tidak merasa kekurangan. Pasangan merasakan bahwa kehidupan pernikahan mereka berjalan dengan baik, selalu merasa cukup dalam hidupnya, serta merasa beruntung dengan kehidupan pernikahannya. Simple appreciation dalam penelitian ini merupakan apresiasi oleh individu terhadap halhal sederhana dalam kehidupan pernikahannya. Dalam hal ini, pasangan mengapresiasi hari demi hari dalam pernikahannya serta mampu memaknai halhal sederhana. Simple appreciation bernilai positif serta signifikan terhadap martal satisfaction, hal tersebut berarti semakin tinggi simple appreciation, maka semakin tinggi pula kepuasan pernikahan.

Social appreciation sebagai dimensi dari rasa syukur memiliki pengaruh yang signifikan dan bernilai positif terhadap kepuasan pernikahan. Dalam penelitian ini, social appreciation merupakan seseorang yang bersyukur akan mengapresiasi orang lain atas kesejahteraan dirinya. Dengan kata lain, seorang istri mengakui bahwa suaminya berkontribusi dalam kehidupannya serta mengapresiasi suaminya atas kesejahteraan dalam hidup.

\section{Saran}

\section{Saran teoritis}

1. Saran untuk penelitian selanjutnya, dapat diteliti kepuasan pernikahan pada sampel laki-laki yang mentalak istri.

2. Dari 50 responden yang mengajukan gugat cerai, ditemukan bahwa marital satisfaction rendah, untuk itu hasil penelitian ini dapat dilanjutkan untuk memprediksi apakah kepuasan pernikahan dapat menjadi prediktor pada pengambilan keputusan bercerai.

\section{Saran praktis}

1. Berdasarkan hasil penelitian ini, ditemukan bahwa dimensi avoidance motivations dan revenge motivations dari pemaafan berpengaruh signifikan terhadap kepuasan pernikahan. Untuk itu, penulis menyarankan pada istri untuk meningkatkan forgiveness atau pemaafan dengan cara tidak menjauh dari suami ketika suami melakukan kesalahan dan tidak membalas kesalahan yang telah dilakukan suami.

2. Pada penelitian ini ditemukan bahwa seluruh dimensi rasa syukur berpengaruh signifikan terhadap kepuasan pernikahan. Untuk itu, penulis menyarankan pada pasangan suami istri untuk saling mengapresiasi hal-hal yang dilakukan pasangannya, lebih memaknai hal-hal sederhana dalam kehidupan pernikahan, serta selalu positif dan berkecukupan dalam kehidupan rumah tangga. 


\section{DAFTAR PUSTAKA}

Ahangar K, Juhari R, Yaacob S and Abu Talib M (2016) Demographic factors and marital satisfaction among Iranian married students in Malaysia. Asian Journal of Social Sciences \& Humanities. 5 (2) 153-63.

Algoe, S. B., Gable, S. L., \& Maisel, N. C. (2010). It's the Little Things: Everyday Gratitude as a Booster Shot for Romantic Relationships. Personal Relationship. 17, 217-233

Berger, A. R., \& Janoff-Bulman, R. (2006). Costs and Satisfaction in Close Relationships: The Role of Loss-Gain Framing. Personal Relationship. 13, 53-68

Fan, C. S, \& Lui, Hon-Kwong. Extramarital affairs, marital satisfaction, and divorce: evidence from hong kong. Contemporary Economic Policy. 22(4), $442-452$

Fenell, D. (1993). Characteristic of Long-term First Marriage. Journal of Mental Health Counseling, 15(4), 446-460

Fincham, F. D., Beach, S. R., \& Davila, J. (2004). Forgiveness and conflict resolution in marriage. Journal of family Psychology, 18, 72-81.

Fincham, F. D., Paleari, \& Regalia, G. (2002). Forgiveness in marriage: the role of relationship quality, attributions, and empathy. Personal Relationship, 9, 27-37.

Fowers, B. J., \& Olson, D. H. (1993). Enrich Marital Satisfaction Scale: A Brief Research and Clinical Tool. Journal of Famil Pschology, 2, 176-185

Igbo., Grace. A. R., \& Ekoja. (2015). Relationship between Duration of Marriage, Personality Trait, Gender, Conflict Resolution Strategies of Spouses. Social and Behavioral Sciences. 190, 490-496

McCullough, M. E., Worthington, E. L., \& Rachal, K. C. (1997). Interpersonal Forgiving in Close Relationship. Journal of Psychology, 2, 321-336.

McCullough, M. E., Sandage, S. J., Brown, S. W., Rachal, K. C., \& Worthington, E. L., Hight, T. L. (1998). Interpersonal Forgiving in Close Relationships: II Theoritical Elaboration and Measurement. Jurnal of Personality and Social Psychology. 75(6), 1586-1603

McCullough, M. E., Root, L. M., \& Cohen, A. D. (2006).Writing About the Benefits of an Interpersonal Transgression Facilitates Forgiveness. Journal of Consulting and Clinical Psychology, 5, 887-897

Mirzadeh, M. \& Fallahchai, R. (2012). The Relationship between forgiveness and marital satisfaction. J. Life Sci. Biomed, 2(6), 278-282.

Olson, D. H., DeFrain, J. (2006). Marriages and Families; Intermacy, Diversity, and Strength $5^{\text {th }}$ ed. Boston; McGraw-Hill

Paleari, F. G., Regalia, C., Fincham, F. (2005). Marital Quality, Forgiveness, Empathy, and Rumination: A Longitudinal Analysis. Personality and Social Psychology Bulletin, 31 (3): 368-78

Pengadilan Agama Jakarta Selatan. (2015). Rekap Faktor Penyebab Perceraian. http://pa-jakartaselatan.go.id/en/2012-03-28-03-32-12/2014-04-08-1601-59/faktor-penyebab-perceraian/faktor-penyebab-perceraian2015.Diakses pada 12 Maret 2016 
Pusat Bahasa Departemen Pendidikan Nasional. (2008). Kamus Besar Bahasa Indonesia. Jakarta: Pusat Bahasa

Rosen-Gradon, J. R., Myers, J. E., \& Hattie, J. A. (2004). The Relationship between Marital Characteristics, Marital Interaction Process, and Marital Satisfaction. Journal of Counseling \& Development, 58-68

Schramm, D. G., Marshall, J. P., Harris, V. W., Lee, T. R. (2005). After I Do: The Newlywed Transition. Marriage and Family Review, 38(1), 45-67

Sharlin, S. A. (1996). Long-Term Succesful Marriage in Israel. Contemporary Family Therapy. 18(2), 225-242

Watkins, P. C., Woodward, K., Stone, T., Kolts, R. L. (2003). Social Behavior and Personality. 31(5), 431-452

Wong, L. C., Chu, A. M. Y., \& Chan, C. L.W. (2014) Measuring TransgressionRelated Interpersonal Motivations Inventory in Marital Relationships: Forgiveness in the Chinese Context (C-TRIM). Research on Social Work Practice. 24(3), 356-363 